\title{
Mixed culture of Pacific white shrimp Litopenaeus vannamei (Boone, 1931) and flathead grey mullet Mugil cephalus (Linnaeus, 1758) in floating cages
}

\author{
SHUBHADEEP GHOSH, RITESH RANJAN, SEKAR MEGARAJAN, PHALGUNI PATTNAIK, \\ BISWAJIT DASH AND LOVESON EDWARD \\ Visakhapatnam Regional Centre of ICAR-Central Marine Fisheries Research Institute, Visakhapatnam - 530003 , \\ Andhra Pradesh, India \\ e-mail: subhadeep_1977@yahoo.com
}

\begin{abstract}
The study explored the possibility of integrating the grey mullet Mugil cephalus (Linnaeus, 1758) along with Pacific white shrimp Litopenaeus vannamei (Boone, 1931) in floating cage culture in Godavary Estuary, India. Post-larvae (PL 12) of L. vannamei (3 lakhs nos.), were acclimatised and nursed in five hapas for 28 days at a density of 3333 nos. $\mathrm{m}^{-2}$, with survival of $60 \%$. L. vannamei juveniles having mean weight of $0.86 \mathrm{~g}$, stocked at a density of 1060 nos. $\mathrm{m}^{-2}$, were cultured along with and without pre-stocked M. cephalus, in three floating cages each. Six thousand fry of M. cephalus (mean length $4.17 \mathrm{~cm}$; mean weight $1.22 \mathrm{~g}$ ) were stocked in three cages at uniform density of $23.5 \mathrm{nos} . \mathrm{m}^{-3}$, three months prior to stocking of L. vannamei. Shrimps were fed commercial pellets @ 3-8\% of body weight, four times daily and harvested after 68 days. Fishes were fed with pelleted feed and after five months attained mean length of $23.7 \mathrm{~cm}$ and mean weight of $274.1 \mathrm{~g}$. Survival was $46.4 \%$ and the average production obtained was $250.2 \mathrm{~kg}$. At harvest, L. vannamei in monoculture system attained mean weight of $13.3 \mathrm{~g}$ and in the mixed culture system, average weight obtained for the shrimps was 13.5 g. Survival, feed conversion ratio (FCR) and production of $L$. vannamei from monoculture were $64.7 \%, 2.0$ and $258.9 \mathrm{~kg}$ and from mixed culture $76.8 \%, 1.6$ and $311.5 \mathrm{~kg}$ respectively. Daily weight increment and specific growth rate (SGR) of L. vannamei was $0.18 \mathrm{~g}$ and 4.06 for monoculture and $0.19 \mathrm{~g}$ and 4.01 for mixed culture, resepectively. Feed conversion, survival and production of $L$. vannamei were significantly $(\mathrm{p}<0.05)$ better in mixed culture, confirming technical superiority of mixed culture over monoculture.
\end{abstract}

Keywords: Cage culture, Growth, Litopenaeus vannamei, Mugil cephalus, Production, Survival

\section{Introduction}

Shrimp aquaculture, is expanding at a very rapid pace globally. Among penaeid shrimps, the Pacific white shrimp, Litopenaeus vannamei (Boone, 1931), is the most important species farmed worldwide. L. vannamei, owing to its high growth rate, euryhaline nature and year round availability of healthy post-larvae (PL), is the preferred crustacean species for coastal aquaculture. The global culture production of L. vannamei in 2010 was 2.6 million $\mathrm{t}$, wherein it accounted for $71.8 \%$ of the world production of all farmed marine shrimp species and $77.8 \%$ of which was produced in Asia (FAO, 2012). India is one of the top producers of farmed shrimp. L. vannamei was introduced to Asia for the first time in China in the year 1996 and thereafter farming commenced on a commercial scale. In India, during the last decade, vast expanse of coastal land is devoted to farming of $L$. vanname which is gradually replacing Penaeus monodon culture. L. vanname $i$ is generally cultured in coastal ponds constructed in estuarine zones and the construction of ponds causes large scale destruction of ecologically important mangrove population (Primavera, 1994). Intensive shrimp culture practices necessitate use of supplementary feed, fertilisers as well as antibiotics and chemotherapeutants which are ultimately discharged into the surrounding environment, leading to deleterious impacts. Coastal areas or estuaries are characterised by weak currents and less water renewal, resulting in shrimps cultured in coastal ponds being exposed to pollutants because of less water dispersal and ultimately leading to disease outbreaks and mass mortality. This points towards the importance and benefits of shrimp farming in floating cages. In floating cages, water exchange is much higher facilitating availability of good water quality and presence of natural food enables less energy intensive operations with minimal environmental harm (Zarain-Herzberg et al., 2006; Chim et al., 2008). There are only very few reports available on farming of $L$. vannamei in floating cages. In cage culture of $L$. vannamei, stocking densities varied widely from 10 nos. $\mathrm{m}^{-2}$ (Cuvin-Aralar et al., 2008) to 2500 nos. $\mathrm{m}^{-2}$ (Paquotte et al., 1998), with 250 nos. $\mathrm{m}^{-2}$ to 500 nos. $\mathrm{m}^{-2}$ (Lombardi et al., 2006; Zarain-Herzberg et al., 2010) being the preferred range. 
Culture of finfish along with shrimp in cages considerably increases production by using available ecological resources (culture area and food sources) in a more efficient way. The flathead grey mullet, Mugil cephalus (Linnaeus, 1758) being hardy, euryhaline and eurythermal with herbivorous feeding habit, offers excellent scope for integrating with L. vannamei. They are filter feeders, feeding predominantly on detritus, diatoms, algae and microscopic invertebrates (McDonough and Wenner, 2003). Juveniles of $L$. vannamei are not consumed by M. cephalus and therefore their survival is unaffected by stocking with mullet. Culturing Nile tilapia (Oreochromis niloticus) with L. vannamei in ponds (Junior et al., 2012) and recirculatory tanks (Muangkeow et al., 2007; Barraza, 2010) has been observed to be productive. Costa et al. (2013) reported on polyculture of $L$. vannamei with Mugil platanus. However, till date, no attempt has been made to integrate L. vannamei farming with $M$. cephalus in cages. The present study was therefore aimed at examining the technical feasibility of co-culturing L. vannamei and M. cephalus in floating cages in Godavari Estuary at Narsapur, Andhra Pradesh, India.

\section{Materials and methods}

Cage site

The site selected for cage farming was at Narsapur (16²0'01.8” N; 8143'05.3" E) in Godavari Estuary. The site was devoid of strong currents, protected from direct wind and wave action and located away from any source of direct pollution from land. Water depth was $6 \mathrm{~m}$ and tidal amplitude was $2 \mathrm{~m}$. Water quality of the site was determined weekly, for a month prior to cage installation and was found to be optimum for cage culture. Salinity of water was $26.5 \pm 0.2 \mathrm{ppt}$, temperature $29.6 \pm 0.1^{\circ} \mathrm{C}, \mathrm{pH}$ $7.8 \pm 0.1$, dissolved oxygen $4.05 \pm 0.05 \mathrm{mgl}^{-1}$ and ammonia nitrogen level was $0.007 \pm 0.001 \mathrm{mgl}^{-1}$. The bottom sediment at the site was muddy-sand.

\section{Cage design}

Six numbers of circular galvanised iron (GI) cages were fabricated locally. The $6 \mathrm{~m}$ dia cage frame was made of ' $\mathrm{B}$ ' class epoxy painted GI pipe ( $5 \mathrm{~cm}$ dia) and was connected to an outer predator net (braided $60 \mathrm{~mm}$ mesh) made of high density polyethylene (HDPE), inner grow-out ( $8 \mathrm{~mm}$ mesh for culture of $M$. cephalus prior to introduction of L. vannamei and $2 \mathrm{~mm}$ and $4 \mathrm{~mm}$ mesh for L. vannamei culture during its first and second month and bird nets ( $80 \mathrm{~mm}$ mesh) with a net depth of $3 \mathrm{~m}$. The joints of the cages were double welded for ensuring extra strength. Hand rail at a height of $1 \mathrm{~m}$ from the base frames was provided for ensuring safety of the workers and to facilitate routine cage management. Bottom circular GI ballast pipe $(5 \mathrm{~cm}$ dia) with perforations was provided to keep the nets in exact shape and volume. Velon screens attached to the ballast pipe were provided over the bottom of inner net as substratum for $L$. vannamei. The effective cage volume and surface area were $85 \mathrm{~m}^{3}$ and $28.3 \mathrm{~m}^{2}$ respectively. Each GI cage was provided with eight pressurised fiber barrels (200 1 capacity) containing 30 psi of air for aiding floatation. Each cage was moored using four galvanised iron poles $(10 \mathrm{~m}$ height and $7.5 \mathrm{~cm} \mathrm{dia})$ each, inserted deep $(2 \mathrm{~m})$ into the estuary bottom. The cages were attached to the poles using GI rings and polypropylene ropes of $13 \mathrm{~mm}$ dia. Cages were moored $10 \mathrm{~m}$ apart from each other to allow sufficient water exchange.

\section{Grow-out rearing of $M$. cephalus}

M. cephalus fry (6000 nos.) measuring $4.17 \pm 0.22 \mathrm{~cm}$ in length and $1.22 \pm 0.13 \mathrm{~g}$ in weight, caught from areas adjacent to the cage site by castnet operations in February, 2014 were randomly stocked in equal numbers in three cages, at a stocking density of 23.5 nos. $\mathrm{m}^{-3}$. Fishes were initially fed thrice a day with commercial floating pellets (Growel Feeds Private Ltd., India) having $22 \%$ crude protein and 3\% crude fat. After two months of grow-out culture, feeding frequency was reduced to twice daily. Fishes were fed @ $8-12 \%$ of body weight, with the ration decreasing with culture duration. Pellets were fed by placing in rectangular polyvinyl chloride (PVC) trays hanged at the bottom from the centre of the cage. Feeding strategy was similar in all the three cages. Fishes were harvested from the cages in the middle of July, 2014 after 5 months of grow-out culture.

\section{Nursery rearing of L. vannamei}

Post-larvae (PL 12) of L. vannamei (3 lakhs nos.) were procured from a commercial hatchery in Pondicherry, India and were air lifted and brought to the cage culture site at Narsapur during April, 2014. Post-larvae were certified to be produced from specific pathogen free (SPF) broodstock maintained in the same hatchery. The PL were transported in oxygenated polythene bags with crushed ice placed in between the inner and outer covers for maintaining optimum temperature. On reaching the farm site, the PL were acclimatised by placing the polythene bags containing PL in hapas in the estuary for about $15 \mathrm{~min}$. This was followed by sprinkling and slow addition of water from the estuary to the polythene bags before releasing the PL into the hapa in estuary. Five hapas of $1 \mathrm{~mm}$ mesh size, measuring $6 \times 3 \times 2$ $\mathrm{m}$ were used. Sixty thousand PL were randomly stocked in each hapa at a stocking density of 3333 nos. $\mathrm{m}^{-2}$. Post-larvae were fed crumbled feed (Avanti Private Ltd., India) with 38\% crude protein distributed equally over four times a day. After 28 days of nursery rearing, juveniles attained an average weight of $0.86 \pm 0.05 \mathrm{~g}$, with an approximate average survival of $60 \%$.

\section{Grow-out rearing of L. vannamei}

Around 1.8 lakhs juveniles $(0.86 \pm 0.05 \mathrm{~g})$ of $L$. vannamei caught from the five hapas were released in May, 2014 randomly into the six cages; three cages pre-stocked with 
M. cephalus (referred to as mixed culture or MX) and three cages without pre-stocked fish (referred to as monoculture or MN). All the six cages were stocked equally with 30000 juveniles' each per cage (1060 nos. $\left.\mathrm{m}^{-2}\right)$. L. vannamei were fed with commercial sinking pellets (Avanti Private Ltd., India) containing $34 \%$ crude protein and $5 \%$ crude fat, uniformly four times a day (06.00 hrs, $10.00 \mathrm{hrs}, 15.00 \mathrm{hrs}$ and $20.00 \mathrm{hrs})$. Feed was applied evenly in four feeding trays suspended above cage bottom from four corners of the cage. Feeding regime followed was $6-8 \%$ of body weight during the first month and 3 - 5\% during the second month. Cylindrical PVC pipes were provided as hide-outs for providing shelter for newly moulted shrimps. The shrimps were harvested from all the six cages in middle of July, 2014 after 68 days of grow-out culture.

Cage maintenance, sampling and growth study

The cages were inspected at every 7 days' interval by underwater diving. Clogging by silt and fouling by barnacles were removed at regular intervals. Daily feed intake of M. cephalus and L. vannamei was assessed from the feed trays and left over feed was collected and weighed. Periodical sampling of $M$. cephalus using hand scoop nets and L. vannamei from feed trays were carried out at regular intervals of 15 days to ascertain their health and growth in all the cages. Total length (TL) and body weight (W) of the samples were measured to the nearest $1 \mathrm{~mm}$ and $0.01 \mathrm{~g}$, respectively. Water samples were collected fortnightly from the cage area and analysed for temperature, $\mathrm{pH}$, dissolved oxygen, ammonia nitrogen and nitrite nitrogen (APHA, 1998).

Total production and survival of $M$. cephalus and L. vannamei were recorded at the end of the culture duration. Important growth parameters viz., weight increment per day (g), specific growth rate (SGR) and feed conversion ratio (FCR) were estimated using following formulae:

Weight increment per day $(\mathrm{g})=$ (Final mean body weight - Initial mean body weight) / Number of days
SGR $=[(\ln$ final mean body weight $-\ln$ initial mean body weight $/$ Number of days] x 100

FCR = Dry weight of feed provided / Wet weight gain

Statistical analysis

The data were evaluated for normality using the Kolmogorov-Smirnov test and Student's t-test was employed to study the differences of growth parameters, survival and production at $5 \%$ probability level.

\section{Results}

\section{Cage environment}

Water quality parameters monitored during the culture period (Table 1) were well within acceptable limits and indicated that cage culture of M. cephalus and L. vannamei has not adversely influenced the environment.

Table 1. Water quality parameters observed during the culture period

\begin{tabular}{lll}
\hline Parameters & Range & Mean \pm SE \\
\hline Salinity $(\mathrm{ppt})$ & $17.0-28.0$ & $23.1 \pm 0.9$ \\
Temperature $\left({ }^{\circ} \mathrm{C}\right)$ & $29.6-31.4$ & $30.6 \pm 0.3$ \\
$\mathrm{pH}$ & $7.4-8.2$ & $7.9 \pm 0.1$ \\
Dissolved oxygen $\left(\mathrm{mg} \mathrm{l}^{-1}\right)$ & $3.6-4.2$ & $3.9 \pm 0.1$ \\
Ammonia nitrogen $\left(\mathrm{mg} \mathrm{l}^{-1}\right)$ & $0.005-0.012$ & $0.008 \pm 0.001$ \\
Nitrite nitrogen $\left(\mathrm{mg} \mathrm{l}^{-1}\right)$ & $0.011-0.020$ & $0.015 \pm 0.002$ \\
\hline
\end{tabular}

\section{Grow-out rearing of $M$. cephalus}

$M$. cephalus fry reached $23.7 \pm 0.4 \mathrm{~cm}$ in length and $274.1 \pm 9.6 \mathrm{~g}$ in weight after five months of culture in cages. The survival rate was $46.4 \pm 1.5 \%$ and average production from each cage was $250.2 \pm 14.0 \mathrm{~kg}\left(2.9 \pm 0.2 \mathrm{~kg} \mathrm{~m}^{-3}\right)$. Details of length, weight and growth parameters at fortnightly intervals are given in Table 2. Daily weight increment and SGR at the time of harvest was $1.8 \pm 0.1 \mathrm{~g}$ and $3.6 \pm 0.0$ respectively.

\section{Grow-out rearing of L. vannamei}

Juveniles of $L$. vannamei in $\mathrm{MN}$, reached $11.9 \pm 0.2 \mathrm{~cm}$ and $13.3 \pm 0.5 \mathrm{~g}$ after 68 days of culture, while in MX, length

Table 2. Length-weight and growth performance (Mean $\pm \mathrm{SE}$ ) of M. cephalus in cage

\begin{tabular}{lllll}
\hline Days of culture & Length $(\mathrm{cm})$ & Weight $(\mathrm{g})$ & Weight increment per day $(\mathrm{g})$ & Specific growth rate \\
\hline 15 & $7.2 \pm 0.2$ & $5.6 \pm 0.4$ & $0.29 \pm 0.02$ & $10.20 \pm 0.07$ \\
30 & $10.9 \pm 0.2$ & $17.1 \pm 1.5$ & $0.53 \pm 0.05$ & $8.80 \pm 0.04$ \\
45 & $12.8 \pm 0.2$ & $36.3 \pm 1.2$ & $0.78 \pm 0.02$ & $7.56 \pm 0.10$ \\
60 & $14.7 \pm 0.3$ & $66.0 \pm 4.2$ & $1.08 \pm 0.07$ & $6.66 \pm 0.02$ \\
75 & $16.1 \pm 0.2$ & $95.8 \pm 4.3$ & $1.26 \pm 0.06$ & $5.83 \pm 0.05$ \\
90 & $17.8 \pm 0.3$ & $129.8 \pm 4.2$ & $1.43 \pm 0.05$ & $5.19 \pm 0.05$ \\
105 & $18.9 \pm 0.2$ & $160.4 \pm 7.3$ & $1.52 \pm 0.07$ & $4.65 \pm 0.03$ \\
120 & $20.5 \pm 0.3$ & $197.7 \pm 9.8$ & $1.64 \pm 0.08$ & $4.25 \pm 0.02$ \\
135 & $22.5 \pm 0.4$ & $243.5 \pm 11.5$ & $1.79 \pm 0.08$ & $3.93 \pm 0.02$ \\
150 & $23.7 \pm 0.4$ & $274.1 \pm 9.6$ & $1.82 \pm 0.06$ & $3.61 \pm 0.03$ \\
\hline
\end{tabular}

${ }^{a}$ Growth performance on each day of culture was calculated from 0 day 
and weight attained were $12.0 \pm 0.3 \mathrm{~cm}$ and $13.5 \pm 0.2 \mathrm{~g}$ respectively. Average length and weight recorded fortnightly for L. vannamei in MN and MX are summarised in Table 3 and details of survival, FCR and production of $L$. vannamei in $\mathrm{MN}$ and MX are presented in Table 4. FCR was significantly $(\mathrm{p}<0.05)$ higher and survival as well as production were significantly $(p<0.05)$ lower in $\mathrm{MN}$, as compared to MX.

Daily weight increment and SGR on days 15, 30, 45, 60 and 68 are presented in Table 5. There was no significant $(\mathrm{p}>0.05)$ difference in daily weight increment and SGR recorded for L. vannamei, between $\mathrm{MN}$ and MX. Daily weight increment and SGR at harvest was $0.18 \pm 0.01 \mathrm{~g}$ and $4.06 \pm 0.04$ for $\mathrm{MN}$ and $0.19 \pm 0.00 \mathrm{~g}$ and $4.01 \pm 0.03$ for MX respectively. SGR was higher the first 15 days of culture and decreased gradualy towards the end. On the contrary, weight increment per day was higher during the later phase of culture.

\section{Discussion}

The cage design and mooring system adopted in the present study were found to be suitable for culture of L. vannamei and M. cephalus. Earlier studies on cage cultured L. vannamei, used hapa net cages (Cuvin-Aralar et al., 2008), rectangular PVC cages (Paquotte et al., 1998; Lombardi et al., 2006; Zarain-Herzberg et al., 2010), circular HDPE cages (Zarain-Herzberg et al., 2010) or rectangular HDPE cages (Sivanandavel and Soundarapandian, 2013). This is the first report on culture of $L$. vannamei in GI floating net cages. There was no disease or water quality problems observed during the culture period, as evident from the regular sampling. Water quality parameters from cage area during culture were within the limits as stated by Boyd and Tucker (1998). Similar values of water quality were observed in cage cultured L. vannamei from other locations (ZarainHerzberg et al., 2010; Ray et al., 2011; Sivanandavel and Soundarapandian, 2013).

Polyculture of $M$. platanus with $L$. vannamei in earthen ponds at densities of 0.67 nos. $\mathrm{m}^{-2}$ for 79 days recorded 82 to 84\% survival and SGR of 3.69 to 3.99 (Costa et al., 2013). In comparison, $M$. cephalus reared in cages in the present study at much higher stocking density of 23.5 nos. $\mathrm{m}^{-3}$ recorded higher weight increment $\left(1.3 \mathrm{~g} \mathrm{day}^{-1}\right)$ and SGR (5.8) on day 75 . Feeding with artificial diet coupled with optimum water quality resulted in improved growth performance of M. cephalus in cages.

Table 3. Length and weight (Mean $\pm \mathrm{SE}$ ) of L. vannamei in monoculture and mixed culture

\begin{tabular}{|c|c|c|c|c|}
\hline \multirow{2}{*}{ Days of culture } & \multicolumn{2}{|c|}{ Monoculture } & \multicolumn{2}{|c|}{ Mixed culture } \\
\hline & Length $(\mathrm{cm})$ & Weight (g) & Length (cm) & Weight (g) \\
\hline 0 & $3.3 \pm 0.0$ & $0.8 \pm 0.0$ & $3.3 \pm 0.1$ & $0.9 \pm 0.0$ \\
\hline 15 & $5.9 \pm 0.1$ & $2.2 \pm 0.2$ & $5.9 \pm 0.2$ & $2.2 \pm 0.1$ \\
\hline 30 & $8.2 \pm 0.1$ & $4.6 \pm 0.3$ & $8.1 \pm 0.2$ & $4.6 \pm 0.1$ \\
\hline 45 & $10.0 \pm 0.1$ & $8.0 \pm 0.4$ & $10.0 \pm 0.2$ & $8.1 \pm 0.2$ \\
\hline 60 & $11.3 \pm 0.1$ & $11.7 \pm 0.6$ & $11.3 \pm 0.2$ & $11.6 \pm 0.4$ \\
\hline 68 & $11.9 \pm 0.2$ & $13.3 \pm 0.5$ & $12.0 \pm 0.3$ & $13.5 \pm 0.2$ \\
\hline
\end{tabular}

Table 4. Survival, FCR and production (Mean $\pm \mathrm{SE}$ ) of L. vannamei in monoculture and mixed culture

\begin{tabular}{lll}
\hline & Monoculture & Mixed culture \\
\hline Survival \% & $64.7 \pm 1.7^{\mathrm{a}}$ & $76.8 \pm 3.0^{\mathrm{b}}$ \\
FCR & $2.0 \pm 0.1^{\mathrm{a}}$ & $1.6 \pm 0.0^{\mathrm{b}}$ \\
Production $\left(\mathrm{kg}\right.$ and $\left.\mathrm{kg} \mathrm{m}^{-2}\right)$ & $258.9 \pm 9.0^{\mathrm{a}}$ and $9.1 \pm 0.3^{\mathrm{a}}$ & $311.5 \pm 17.1^{\mathrm{b}}$ and $11.0 \pm 0.6^{\mathrm{b}}$
\end{tabular}

${ }^{a}$ Mean values with different superscripts between columns in each row indicate significant $(\mathrm{p}<0.05)$ differences (between monoculture and mixed culture)

Table 5. Weight increment and specific growth rate (Mean $\pm \mathrm{SE})$ of L. vannamei in monoculture and mixed culture

\begin{tabular}{|c|c|c|c|c|}
\hline \multirow{2}{*}{ Days of culture } & \multicolumn{2}{|c|}{ Weight increment per day (g) } & \multicolumn{2}{|c|}{ Specific growth rate (SGR) } \\
\hline & Monoculture & Mixed culture & Monoculture & Mixed culture \\
\hline 15 & $0.09 \pm 0.02^{\mathrm{a}}$ & $0.09 \pm 0.01^{\mathrm{a}}$ & $6.33 \pm 0.64^{\mathrm{a}}$ & $6.07 \pm 0.26^{\mathrm{a}}$ \\
\hline 30 & $0.12 \pm 0.01^{\mathrm{a}}$ & $0.12 \pm 0.00^{\mathrm{a}}$ & $5.63 \pm 0.18^{\mathrm{a}}$ & $5.48 \pm 0.09^{\mathrm{a}}$ \\
\hline 45 & $0.16 \pm 0.01^{\mathrm{a}}$ & $0.16 \pm 0.00^{\mathrm{a}}$ & $4.99 \pm 0.08^{\mathrm{a}}$ & $4.92 \pm 0.05^{\mathrm{a}}$ \\
\hline 60 & $0.18 \pm 0.01^{\mathrm{a}}$ & $0.18 \pm 0.01^{\mathrm{a}}$ & $4.39 \pm 0.07^{\mathrm{a}}$ & $4.30 \pm 0.05^{\mathrm{a}}$ \\
\hline 68 & $0.18 \pm 0.01^{\mathrm{a}}$ & $0.19 \pm 0.00^{\mathrm{a}}$ & $4.06 \pm 0.04^{\mathrm{a}}$ & $4.01 \pm 0.03^{\mathrm{a}}$ \\
\hline
\end{tabular}

${ }^{a}$ Mean values for each growth parameter with different superscripts between columns in each row, for each day indicate significant $(\mathrm{p}<0.05)$ differences (between monoculture and mixed culture)

bIncrement and SGR on each day of culture was computed from 0 day 
Growth of $L$. vannamei is sensitive to cultivation density during the nursery stage (Moss and Moss, 2004). Lower rearing densities ranging from 500 to 1600 nos. $\mathrm{m}^{-2}$ during nursery phase before cage stocking were reported by earlier authors (Paquotte et al., 1998; Lombardi et al., 2006; Cuvin-Aralar et al., 2008; Zarain-Herzberg et al., 2010). Zarain-Herzberg et al. (2010) reported survival of 65.8 to $76.7 \%$ and $1.2 \mathrm{~g}$ weight increment after rearing post-larvae for 38 days. The same authors observed higher survival and growth at lower stocking density. In the present study, with much higher stocking density, similar growth of L. vannamei post-larvae was observed. This could be attributed to the fact that post-larvae were fed four times daily with crumbled feed containing $38 \%$ crude protein.

Production of farmed aquatic species in cages appears to be far superior when compared to farming in ponds and tanks. The natural and continuous renewal of water in cages provides optimum water quality in and around cage sites. Water quality is similar to that of the natural environment of the species. Bio-fouling on net coupled with continuous supply of phytoplankton and zooplankton, supplements the nutritional deficiencies in the pelleted feed (Paquotte et al., 1998). L. vannamei were reared in marine cages (Lombardi et al., 2006; Zarain-Herzberg et al., 2010) at densities ranging from 250 to 500 nos. $\mathrm{m}^{-2}$, while in the present study, it was reared in estuary at density of 1060 nos. $\mathrm{m}^{-2}$. Daily growth increment and survival observed in marine cages (Lombardi et al., 2006; Zarain-Herzberg et al., 2010) varied from 0.12 to $0.27 \mathrm{~g}$ and 70 to $80 \%$ respectively. Similar growth increments of 0.18 to $0.19 \mathrm{~g}$ per day and survival of 64.7 to $76.8 \%$ were obtained at higher stocking density, in the present study in Godavary Estuary. FCR was similar to earlier reports (Paquotte et al., 1998; Lombardi et al., 2006; Cuvin-Aralar et al., 2008; Zarain-Herzberg et al., 2010) from cage culture. Growth performance, survival and feed conversions of cage cultured L. vannamei in estuarine and marine environment are similar. However because of higher density used in the present study in estuary, production of L. vannamei was higher $\left(9.1 \mathrm{~kg}-11.0 \mathrm{~kg} \mathrm{~m}^{-2}\right)$ than that reported earlier from both marine and low saline cages (0.8 - $8.0 \mathrm{~kg} \mathrm{~m}^{-2}$ ) (Paquotte et al., 1998; Lombardi et al., 2006; Cuvin-Aralar et al., 2008; Zarain-Herzberg et al., 2010; Sivanandavel and Soundarapandian, 2013). The present study reports the highest production of $L$. vannamei obtained till date from cage farming. The use of cylindrical PVC pipes as hide-outs for shelter of newly moulted shrimps reduced cannibalism with subsequent higher survival, thus enabling culture at high density. Moss and Moss (2004) and Arnold et al. (2006) reported on the use of artificial substrates for increasing survival and negating the effect of density in shrimp culture. The use of velon screen as substrate at the bottom could have contributed to the success of high density farming in the present study. Increments in weight increased with advancement of culture. SGR decreased with increase in weight of shrimp. Jobling (1994) reported on an inverse relationship between SGR and weight, which are in full agreement to the present study.

Integrating species from different trophic levels or species having different feed preferences in the same aquatic system maximises resource utilisation and reduces adverse environmental impacts (Troell et al., 2003; Yuan et al., 2010). Therefore, exploiting differential feeding behaviour and stocking species occupying different spatial niches enables efficient utilisation of space and natural food resources. The same concept was attempted in the present study, by stocking two complementary species occupying inferior trophic levels (herbivore and omnivore), L. vannamei and M. cephalus, for increasing production from cage. M. cephalus obtain majority of their food from the water column (Cardona and Castello, 1994), whereas L. vannamei is a benthic feeder. Survival, feed conversions and production of $L$. vannamei was significantly better in MX than in MN. However, weight increment and SGR did not vary. Similar to the present observation, Junior et al. (2012) stated that fish and L. vannamei growth rates are not inter-dependent, and they do not interfere with the development of each other in mixed culture systems. It is evident that with similar growth rates in MN and MX, production was higher in MX because of higher survival. With similar feeding ration, lower FCR in MX than in $\mathrm{MN}$ is because of higher survival in MX, resulting in better feed conversions. Fish, as they are neither susceptible nor carriers of shrimp viruses, helps to prevent transmission of viruses (Yi et al., 2002; Cruz et al., 2008). Higher survival of L. vannamei in MX could also be attributed to inhibiting effect of mullets on certain pathogenic microorganisms. The slime of mullets produces enzymes that can inhibit the growth of pathogenic Gram-negative bacteria and support growth of probiotic Gram-positive bacteria, benefitting L. vannamei. Similar observations on higher survival of shrimps, when co-cultured with tilapia were reported by Yi et al. (2002) and Cruz et al. (2008). "Detrital rain" from fecal matter of $M$. cephalus contributed to higher food availability and better performance of L. vannamei in MX (Yi et al., 2002; Yuan et al., 2010). Similar, higher survival and net shrimp yield in MX than in MN has been widely reported by various authors (Akiyama and Anggawati, 1998; Tian et al., 2001; Jana et al., 2007) and they opined that better water quality in MX to be the contributing factor when compared to MN. In contrary, Costa et al. (2013) observed deteriorated growth of $L$. vannamei when cultured with $M$. platanus in earthen ponds. According to them, L. vannamei grew $18.8 \%$ more in the absence of $M$. platanus, while $M$. platanus increased by $27.3 \%$ in mixed culture. They attributed reduced growth of L. vannamei in mixed culture to competition for food with mullets, as both the species were in the same environment and had free access to the same feed. However in the present 
study, since both $L$. vannamei and $M$. cephalus were fed separately and optimally, there was no contest for food and growth was similar in MN and MX.

Production of L. vannamei in MX was significantly higher than in MN. Performance indicators in MX firmly confirm its technical feasibility, since both species complemented each other and did not interfere in their growth. Mixed culture of L. vannamei at high density with M. cephalus permitted optimal utilisation of the available space inside cages, thus contributing substantially in improving the technical and the economic aspects of shrimp farming in open waters. However, caution needs to be exercised on issues of potential biosecurity, caused by escape of $L$. vannamei into open waters as it is an exotic species and can have deleterious impacts on the indigenous shrimp population in the region, threatening biodiversity. The present findings indicate feasibility of mixed culture of compatible species in cages using resource-efficient approach. Optimisation and inclusion of other commercially important resources are future researchable areas.

\section{Acknowledgements}

The authors express their sincere thanks to the Director, ICAR-CMFRI, Kochi for the constant support and encouragement. The authors are highly indebted to Mr. V. Srinivasa Raju for his help in maintaining the cage farm.

\section{References}

Akiyama, D. M. and Anggawati, A. M. 1999. Polyculture of shrimp and tilapia in East Java. American Soybean Association (ASA), Technical Bulletin AQ 47.

APHA 1998. Standard methods for the examination of water and wastewater, $20^{\text {th }}$ edn. American Public Health Association, Washington DC, USA.

Arnold, S. T., Sellars, M. J., Crocos, P. J. and Coman, G. J. 2006. Intensive production of juvenile tiger shrimp Penaeus monodon: an evaluation of stocking density and artificial substrate. Aquaculture, 261: 890-896.

Barraza, C. A. H. 2010. Analyses of productivity of Nile tilapia (Oreochromis niloticus), red tilapia (O. niloticus $x$ O. mossambicus) and Pacific white shrimp (Litopenaeus vannamei) polyculture in a recirculating system. $\mathrm{Ph} . \mathrm{D}$. Dissertation, Dept. of Soil Water and Environmental Science, University of Arizona, USA, 192 pp.

Boyd, C. E. and Tucker, C. S. 1998. Pond aquaculture water quality management. Kluwer Academic Publishers, Boston, Massachusetts, USA, $700 \mathrm{pp}$.

Cardona, L. and Castello, F. 1994. Relative importance of plankton and benthos as food sources for Mugil cephalus and Liza ramada in Israeli semi-intensive fish ponds. Israeli $J$. Aquacult. Bamidgeh, 46(4): 197-202.
Chim, L., Castex, M., Pham, D., Brun, P., Lemaire, P., Wabete, N., Schmidely, P. and Mariojouls, C. 2008. Evaluation of floating cages as an experimental tool for marine shrimp culture studies under practical earthen conditions. Aquaculture, 279: 63-69.

Costa, L. C. D. E., Xavier, J. A. A., Neves, L. F. D. M., Azambuja, A. M. V. D., Junior, W. W. and Figueiredo, M. R. C. 2013. Polyculture of Litopenaeus vannamei shrimp and Mugil platanus mullet in earthen ponds. Revista Brasileira de Zootecnia, 42: 605-611.

Cruz, P. S., Andalecio, M. N., Bolivar, R. B. and Fitzsimmons, K. 2008. Tilapia-shrimp polyculture in Negros Island, Philippines: A review. J. World Aquac. Soc., 39: 713-725.

Cuvin-Aralar, M. L. A., Lazartigue, A. G. and Aralar, E. V. 2008. Cage culture of the Pacific white shrimp Litopenaeus vannamei (Bonne, 1931) at different stocking densities in a shallow eutrophic lake. Aquac. Res., 209 (40): 181-187.

FAO 2012. The state of world fisheries and aquaculture 2012. Food and Agriculture Organization, Rome, Italy, $207 \mathrm{pp}$.

Jana, T. K., Banerjee, R. D. and Jana, B. B. 2007. Responses of some bio-geochemical cycling bacteria and their activities to management protocols under polyculture with Indian major carps and freshwater giant prawn. Aquaculture, 264: 184-196.

Jobling, M. 1994. Fish bioenergetics. Chapman and Hall, London, UK, 309 pp.

Junior, A. P. B., Azevedo, C. M. D. S. B., Pontes, F. S. T. and Henry-Silva, G. G. 2012. Polyculture of Nile tilapia and shrimp at different stocking densities. R. Bras. Zootec., 41(7): 1561-1569.

Lombardi, J. V., Marquez, H. L. A., Toledo, R., Pereira, L., Barreto, O. J. S. and Paula, E. J. 2006. Cage polyculture of the Pacific white shrimp Litopenaeus vannamei and the Philippines seaweed Kappapphycus alvarezii. Aquaculture, 258: 412-415.

Maguire, G. B. and Bell, J. D. 1981. The effects of fish on growth and survival of school prawns Metapenaeus macleayi (Haswell) in some Australian brackish water farming ponds. Aquaculture, 24: 267-283.

McDonough, C. J. and Wenner, C. A. 2003. Growth, recruitment and abundance of juvenile Mugil cephalus in South Carolina Estuaries. Fish. Bull., 101: 343-357.

Moss, S. M. and Moss, K. R. K. 2004. Effect of artificial substrate and stocking density on the nursery production of pacific white shrimp Litopenaeus vannamei. J. World Aquac. Soc., 35(4): 536-542.

Muangkeow, B., Ikejima, K. and Powtongsook, S. 2007. Effects of white shrimp, Litopenaeus vannamei (Boone) and Nile tilapia, Oreochromis niloticus L., stocking density on growth, nutrient conversion rate and economic return in integrated closed recirculation system. Aquaculture, 269: 363-376.

Palmer, P. J., Morrison, C., Rutherford, B. W. and Pledger, B. K. D. 2011. Investigations into the potential for mixed cultures of banana prawns Penaeus mergueinsis, sea mullet Mugil cephalus and rabbitfish Siganus nebulosus for bioremediation 
of aquaculture waste. Project report on "Wastewater remediation options for prawn farms", Aquaculture Industry Development Initiative, Queensland, Australia, p. 40- 49.

Paquotte, P., Chim, L., Marin, J. L. M., Lemos, E., Stern, M. and Tosta, G. 1998. Intensive culture of shrimp Penaeus vannamei in floating cages: zootechnical, economic and environmental aspects. Aquaculture, 164: 151-166.

Primavera, J. H. 1994. Environmental and socio-economic effects of shrimp farming: the Philippine experience. Infofish International, 94: 44-49.

Ray, A. J., Dillon, K. S. and Lotz, J. M. 2011. Water quality dynamics and shrimp (Litopenaeus vannamei) production in intensive, mesohaline culture systems with two levels of biofloc management. Aquac. Eng., 45 (3): 127-136.

Sivanandavel, P. and Soundarapandian, P. 2013. Cage erection and hideouts on growth, survival and production of Indian white shrimp, Penaeus indicus (H. Milne Edwards) in Vellar Estuary. Scientific Reports, 2: 589.

Tian, X., Li, D., Dong, S., Yan, X., Qi, Z., Liu, G. and Lu, J. 2001. An experimental study on closed-polyculture of penaeid shrimp with tilapia. Aquaculture, 202 (1-2): 57-71.
Troell, M., Halling, C., Neori, A., Chopin, T., Buschmann, A. H., Kautsky, N. and Yarish, C. 2003. Integrated mariculture: asking the right questions. Aquaculture, 226: 69-90.

Yi, Y., Saelee, W., Naditrom, P. and Fitzsimmons, K. 2002. Stocking densities for tilapia-shrimp polyculture in Thailand. Twentieth annual technical report, Pond Dynamics/Aquaculture, Collaborative Research Support Program, Oregon State University, Corvallis, Oregon, USA.

Yuan, D., Yang, Y., Yakupitiyage, A., Fitzsimmons, K. and Diana, J. S. 2010. Effects of addition of red tilapia (Oreochromis spp.) at different densities and sizes on production, water quality and nutrient recovery of intensive culture of white shrimp (Litopenaeus vannamei) in cement tanks. Aquaculture, 298: 226-238.

Zarain-Herzberg, M., Campa-Codova, A. and Cavalli, R. O. 2006. Biological viability of producing white shrimp Litopenaeus vannamei in seawater floating cages. Aquaculture, 259: 283-289.

Zarain-Herzberg, M., Fraga, I. and Hernandez-Llamas, A. 2010. Advances in intensifying the cultivation of the shrimp Litopenaeus vannamei in floating cages. Aquaculture, 300: 87-92. 